\title{
PENERAPAN MODEL BRAIN-BASED LEARNING TERHADAP PENINGKATAN KARAKTER PESERTA DIDIK KELAS II SEKOLAH DASAR
}

\author{
Irman Syarif ${ }^{1}$; Rahmat ${ }^{2}$ \\ ${ }^{1,2}$ Pendidikan Guru Sekolah Dasar, STKIP Muhammadiyah Enrekang.
}

Jalan Jenderal Sudirman No. 17 Enrekang, Sulawesi Selatan 91712, Indonesia

E-mail: 1issaq_abbas@yahoo.co.id, 2rahmatrjmamat@gmail.com.

\begin{abstract}
Abstrak
Tujuan dari penelitian ini adalah untuk meningkatkan karakter melalui penerapan model BrainBased Learning di kelas II SDN 172 Enrekang. Penelitian ini merupakan Penelitian Tindakan Kelas (PTK), yang dilaksanakan dalam dua siklus. Subjek penelitian ini adalah siswa kelas II SDN 172 Enrekang tahun ajaran 2017/2018 yang berjumlah 30 peserta didik. Teknik pengumpulan data menggunakan teknik observasi, wawancara, angket, dan dokumentasi. Uji validitas data yang digunakan dalam penelitian ini adalah triangulasi sumber dan teknik.Teknik analisis data adalah model analisis interaktif yang terdiri dari tiga komponen yaitu reduksi data, sajian data, dan penarikan kesimpulan atau verifikasi.Simpulan penelitian ini adalah penggunaan model Brain-Based Learning dapat meningkatkan karakter peserta didik kelas II SDN 172 Enrekang tahun ajaran 2017/2018.
\end{abstract}

Kata kunci: Brain-Based Learning, Karakter Siswa,

\section{PENDAHULUAN}

Masalah karakter bangsa kini menjadi perhatian besar oleh pemerintah. Salah satu program pendidikan dari pemerintah adalah memberi penekanan pada pendidikan karakter. Wibowo (2012: 5) menyatakan bahwa "pendidikan karakter hadir sebagai solusi problem moralitas dan karakter". Pendidikan karakter menjadi tanggung jawab bersama antara pemerintah, masyarakat, keluarga dan sekolah. Kondisi seperti inilah yang menjadikan pendidikan karakter semakin penting untuk terus dikaji sehingga dapat diperbaiki dan ditingkatkan efektivitas dalam pembentukan karakter perserta didik, Oleh karena itu, perwujudan nilai-nilai karakter pada semua lapisan masyarakat Indonesia perlu didukung dengan perangkat kebijakan terpadu, salah satunya melalui pendidikan.

Menurut Lickona (1991, p.6) bahwa "down through history, in countries all over the world, education has had two great goals: to help young people become smart and to help them become good". Sehingga pendidikan merupakan sarana yang paling tepat dan besar dalam pembentukan nilai-nilai karakter serta memajukan suatu bangsa karena maju mundurnya sebuah bangsa sangat tergantung dari dorongan serta karakter bangsanya itu sendiri.

Pendidikan karakter hendaknya dimulai dan menjadi prioritas pada jenjang pendidikan dasar (Basic Education). Semakin dini menanamkan karakter, maka karakter tersebut akan semakin kuat, sehingga penanaman nilai-nilai karakter di SD sangat mutlak diperlukan. Hal ini sesuai dengan Piaget (Berk, 2007, p.298) bahwa "Concrete operational stage, which extends from 7 to 11 years and marks a major turning point in cognitive development. Thought is far more logical, flexible, and organized than it was earlier". Dengan demikian pada masa sekolah dasar akan lebih mudah membentuk dan

\#\# HowToCite\#\# 
mengembangkan karakter yang positif. Senada yang dikemukakan oleh Bredekamp dan Rosegrant (1992) menjelaskan bahwa pendidikan yang diberikan kepada anak hendaknya pendidikan yang patut sesuai dengan tahapan perkembangan anak (developmentally appropriate practices/DAP).

Megawangi, dkk (2004) mengatakan bahwa penerapan konsep DAP dalam pendidikan anak akan memungkinkan pendidik untuk memperlakukan anak sebagai individu yang utuh (the whole child) dengan melibatkan 4 komponen dasar yang ada pada diri anak, yaitu pengetahuan (knowledge), keterampilan (skills), sifat alamiah (dispositions), dan perasaan (feelings). Dengan melibatkan semua komponen tersebut secara bersamaan, maka perkembangan intelektual, sosial, dan karakter anak dapat terbentuk secara simutan. Hal ini tentunya, menjadi dasar bahwa pola pendidikan karakter pada anak harus sesuai kemampuan alamiah anak belajar, yakni dengan prinsip perkembangan dan bekerjanya struktur dan fungsi otak anak. Salah satu model pembelajaran yang dapat mengakomodasi hal tersebut dengan model Brain-Based Learning (BBL) (Jensen, 2011: 6)

\section{Model Brain-Based Learning}

merupakan pembelajaran yang berorientasi pada upaya pemberdayaan potensi otak peserta didik. Tiga strategi utama yang dapat dikembangkan dalam implementasi model Brain-Based Learning. Pertama, menciptakan lingkungan belajar yang menantang kemampuan berpikir siswa Ismail, I., Busa, Y., \& Tini, T. (2018). Kedua menciptakan lingkungan pembelajaran yang menyenangkan. Ketiga menciptakan situasi pembelajaran yang aktif dan bermakna bagi siswa (active processing) (Syafaat, 2007).

Model Brain-Based Learning bertujuan untuk mengembangkan lima sistem pembelajaran alamiah otak yang dapat mengembangkan potensi otak dengan maksimal. Kelima sistem pembelajran tersebut adalah sistem pembelajaran emosional, social, kognetif, fisik, dan reflektif. Kelima pembelajaran tersebut saling mempengaruhi dan tidak dapat berdiri sendiri (Given, 2007). Dengan melibatkan kelima sistem tersebut secara bersamaan, maka pendidikan karakter peserta didik dapat berkembang secara simutan.

Model Brain-Based Learning dilaksanakan dengan tujuh tahap pembelajaran yaitu:
1.) Tahap Pra-paparan, yaitu tahap membantu otak mengembangkan peta konseptual yang lebih baik;

2.) Tahap Persiapan, pada tahap ini, guru harus dapat menciptakan keingin-tahuan atau kegembiraan pada siswa terhadap kegiatan pembelajaran;

3.) Tahap Inisiasi dan Akuisisi, Pada tahap ini siswa dibanjiri dengan konten-konten pembelajaran. Guru harus memberikan pengalaman belajar yang nyata kepada siswa dengan menggunakan berbagai sumber akuisisi;

4.) Tahap Elaborasi, tahap ini merupakan tahap pengolahan materi pembelajaran. Pada tahap elaborasi diperlukan keterampilan berpikir siswa dalam mengolah informasi pembelajaran;

5.) Tahap Inkubasi dan Pengkodean Memori. Pada tahap ini waktu istirahat dan waktu pengulangan kembali menjadi sebuah hal yang penting dan sangat ditekankan;

6.) Tahap Verifikasi dan Pengecekan Keyakinan. Selain guru, siswa perlu mengkonfirmasi pemahaman yang mereka peroleh dari pembelajaran yang telah dilakukan untuk diri mereka sendiri dan

7.) Tahap Selebrasi dan Integrasi, pada tahap ini, sangat penting untuk melibatkan emosi. Tahap ini menanamkan arti penting akan rasa kecintaan terhadap belajar. Buatlah tahap ini menjadi menyenangkan, ceria, dan menggembirakan (Jensen, 2011: 298).

Berdasarkan hasil observasi dan wawancara di SDN 172 Enrekang diperoleh nilai afektif peserta didik belum memuaskan. Hal ini tentunya perlu penangan yang baik dalam menanamkan nilai-nilai karakter. Berdasarkan latar belakang yang telah diuraikan, maka peneliti melakukan perbaikan proses pembelajaran melalui penelitian tindakan kelas dengan judul "Penerapan model BrainBased Learning tehadap peningkatan karakter peserta didik kelas II di SDN 172 Enrekang".

\section{METODE PENELITIAN}

Penelitian ini menggunakan rancangan Penelitian Tindakan Kelas (PTK). Lokasi atau tempat penelitian di SDN 172 Enrekang. Subjek penelitian ini difokuskan pada Guru dan Peserta didik kelas II SDN I72 Enrekang. Yang berjumlah dari 30 orang Peserta didik, yang terdiri dari 12 orang putra dan 18 orang putri pada semester I (Genap) tahun pelajaran 2017/2018. Penelitian 
tindakan kelas ini terdiri atas dua siklus. Setiap siklus dilakukan 5 rangkaian kegiatan. Lima kegiatan utama yang ada pada setiap siklus menurut Arikunto (2007: 74) yaitu: (1) Pra tindakan, (2) Perencanaan, (3) Tindakan, (4) Observasi dan (5) Refleksi.

Teknik yang digunakan dalam penelitian ini yaitu Observasi untuk menggali data mengenai karakter Peserta didik, dan wawancara untuk menggali data mengenai kendala-kendala yang dihadapi selama pembelajaran. Data yang diperlukan dalam penelitian ini adalah (1) data karakter Peserta didik; (2) kendala-kendala selama pembelajaran. Serta, Instrumen yang digunakan dalam penelitian ini meliputi instrument observasi dan instrumen angket.

\section{HASIL DAN PEMBAHASAN}

Berdasarkan hasil observasi karakter peserta didik Pada siklus I diperoleh data bahwa peserta didik kelas II SDN 172 Enrekang yang mengikuti pembelajaran dengan menerapkan model Brain-Based Learning (BBL) diperoleh nilai rata-rata setiap karakter yang tertanam. Untuk lebih jelasnya dapat dilihat pada tabel berikut

Tabel 1. Nilai hasil observasi karakter Peserta didik siklus I

\begin{tabular}{|l|c|c|c|c|}
\hline \multirow{2}{*}{ Karakter } & \multicolumn{3}{|c|}{ Siklus I } & \multirow{2}{*}{$\begin{array}{c}\text { Rata- } \\
\text { rata\% }\end{array}$} \\
\cline { 2 - 4 } & \multicolumn{2}{|c|}{ Pertemuan Ke- } \\
\cline { 2 - 4 } & 1 & 2 & 3 & \\
\hline Disiplin & 75 & 80 & 87 & 80.7 \\
\hline Kejujuran & 55 & 67 & 70 & 64 \\
\hline Religius & 77 & 80 & 80 & 79 \\
\hline Rasa Ingin Tahu & 75 & 79 & 80 & 78 \\
\hline Kemandirian & 57 & 65 & 60 & 60.7 \\
\hline Kerjasama & 67 & 70 & 68 & 68 \\
\hline Integritas & 59 & 67 & 77 & 67.7 \\
\hline Cintai damai & 63 & 69 & 80 & 70.7 \\
\hline
\end{tabular}

Berdasarkan pada tabel 1 diperoleh nilai rata-rata setiap karakter yang tertanam yaitu pada karakter Disiplin dengan nilai persentase $80.7 \%$ dengan kriteria baik. Untuk karakter kejujuran diperoleh nilai persentase 64\% dengan kriteria cukup. Nilai karakter religuis diperoleh nilai persentase $79 \%$ dengan kriteria cukup. Nilai karakter Rasa Ingin Tahu diperoleh nilai persentase $78 \%$ dengan kriteria cukup. Nilai karakter Kemandirian diperoleh nilai persentase $60.7 \%$ dengan kriteria cukup. Nilai karakter Kerjasama diperoleh nilai persentase $68 \%$ dengan kriteria cukup. Nilai karakter Integritas diperoleh nilai persentase $67.7 \%$ dengan kriteria cukup. Nilai karakter Cinta damai diperoleh nilai persentase $60.7 \%$ dengan kriteria cukup.

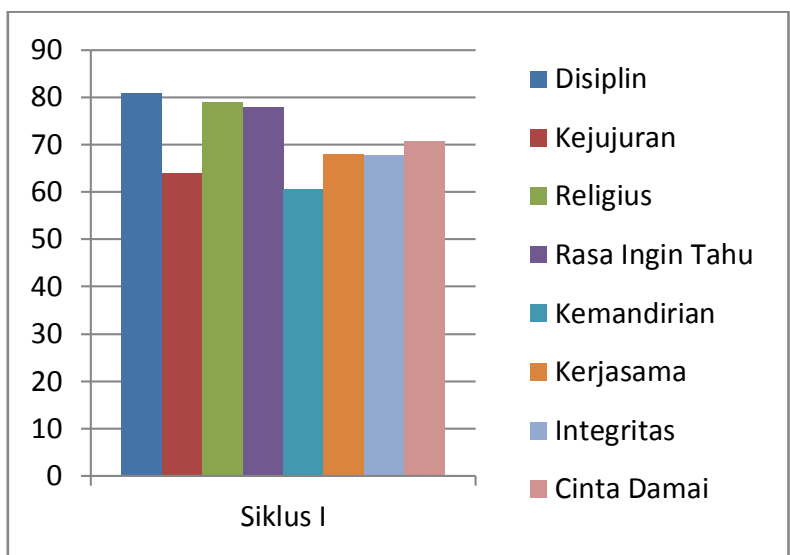

Gambar 1. Grafik nilai rata-rata karakter peserta didik Siklus I

Pada siklus II terjadi peningkatan nilai rata-rata setiap karakter yang tertanam. Untuk lebih jelasnya dapat dilihat pada tabel berikut

Tabel 1. Nilai Hasil Observasi Karakter Peserta Didik siklus II

\begin{tabular}{|l|c|c|c|c|}
\hline \multirow{3}{*}{ Karakter } & \multicolumn{3}{|c|}{ Siklus II } & \multirow{2}{*}{ Rata- } \\
\cline { 2 - 4 } & \multicolumn{2}{|c|}{ Pertemuan Ke- } & rata\% \\
\cline { 2 - 4 } & 1 & 2 & 3 & \\
\hline Disiplin & 87 & 95 & 90 & 91.7 \\
\hline Kejujuran & 78 & 80 & 83 & 80 \\
\hline Religius & 85 & 91 & 95 & 90 \\
\hline Rasa Ingin Tahu & 82 & 80 & 85 & 82 \\
\hline Kemandirian & 70 & 79 & 82 & 77 \\
\hline Kerjasama & 70 & 75 & 79 & 74 \\
\hline Integritas & 75 & 80 & 83 & 79 \\
\hline Cintai damai & 76 & 82 & 85 & 81 \\
\hline
\end{tabular}

Berdasarkan pada tabel 2 diperoleh nilai rata-rata setiap karakter yang tertanam yaitu karakter Disiplin dengan nilai persentase 91.7\% dengan kriteria sangat baik. Untuk karakter kejujuran diperoleh nilai persentase $80 \%$ dengan kriteria baik. Nilai karakter religuis diperoleh nilai persentase $90 \%$ dengan kriteria sangat baik. Nilai karakter Rasa Ingin Tahu diperoleh nilai persentase $82 \%$ dengan kriteria baik. Nilai karakter Kemandirian diperoleh nilai persentase $77 \%$ dengan kriteria cukup. Nilai karakter Kerjasama diperoleh nilai persentase $74 \%$ dengan kriteria cukup. Nilai karakter Integritas diperoleh nilai persentase 79\% dengan kriteria cukup. Nilai karakter Cinta 
damai diperoleh nilai persentase $81 \%$ dengan kriteria baik.

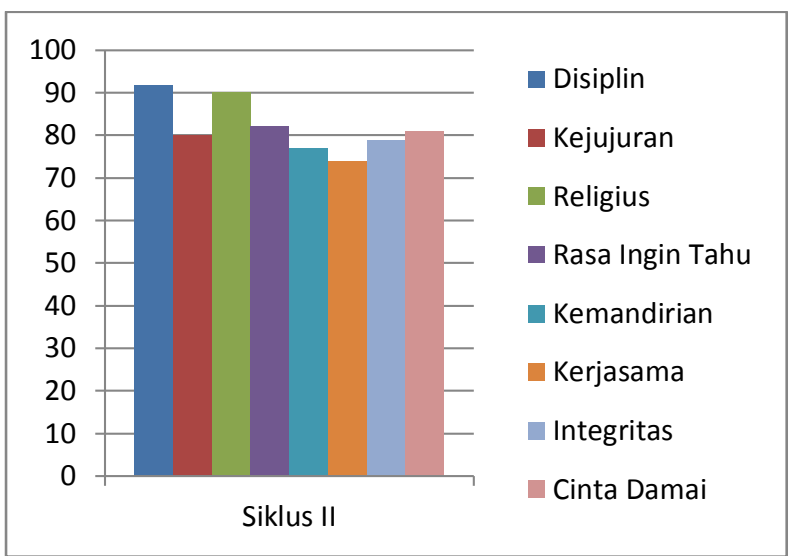

Gambar 2. Grafik nilai rata-rata karakter peserta didik Siklus II

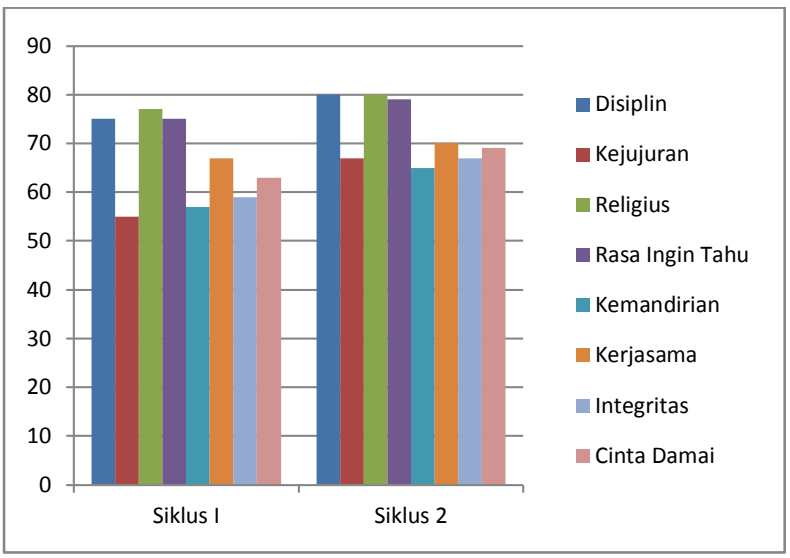

Gambar 3. Grafik Nilai rata-rata karakter Peserta didik Siklus I dan II

Berdasarkan gambar 3 dapat menunjukkan bahwa terdapat peningkatan yang signifikan terhadap persentase nilai rata-rata karakter peserta didik kelas I SDN II Enrekang. Hal tersebut menunjukkan bahwa indikator yang ditargetkan telah tercapai bahkan melebihi indikator yang ditargetkan. Dari data-data tersebut, maka dengan demikian tindakan yang telah diberikan selama penelitian dikatakan berhasil, sehingga penelitian dihentikan.

\section{SIMPULAN}

Penerapan model Brain-Based Learning (BBL) di Kelas II Sekolah Dasar menunjukkan bahwa nilai-nilai karakter tersebut dapat berkembang dengan baik. Data hasil observasi karakter peserta didik pada setiap siklus nya terjadi peningkatan Hal ini menunjukan bahwa melalui Penerapan SSP Tematik dapat meningkatkan hasil belajar dan karakter peserta didik kelas II SDN 172 Enrekang.

\section{DAFTAR PUSTAKA}

Berk, L. E. (2007). Development through the lifespan. Boston: Pearson Allyn and Bacon.

Bredekamp, S., \& Rosegrant, T. (1992). Reaching Potentials: Appropriate Curriculum and Assessment for Young Chil- dren, Volume 1. Washington: National Association for The Education of Young Children.

Given, B.K. 2007. Brain Based Teaching (Merancang Kegiatan Belajar-Mengajar yang Melibatkan Otak, Emosional, Sosial, Kognitif, Kinestetis, dan Reflektif). Bandung: Kaifa.

Ismail, I., Busa, Y., \& Tini, T. (2018). Parental involvement in fostering the character of children's discipline at elementary school. Jurnal Pendidikan Progresif, 8(2), 53-67.

Jensen, Eric. Pemelajaran Berbasis Otak Paradigma Pengajaran Baru. Jakarta: Indeks, 2011.

Lickona, T. (1991). Educating for character: How our schools can teach respect and responsibility. New York: Bantam Books.

Megawangi, Ratna, dkk. (2004). Pendidikan yang Patut dan Menyenangkan: Penerapan Teori Developmentally Appropriate Practices (DAP) Anak-anak Usia Dini 0 sampai 8 tahun. Cimanggis: Indonesia Heritage Foundation.

Suharsimi, Arikunto. (2007). Prosedur Penelitian, Suatu Pendekatan Praktik. Rineka Cipta: Jakarta.

Wibowo, A. (2012). Pendidikan Karakter: Strategi Membangun Karakter Bangsa Berperadaban. Yogyakarta. 